\title{
Bread Wheat Varietal Development and Release in Southeastern Highlands of Ethiopia
}

\author{
Tamene Mideksa ${ }^{1,}$, Tesfaye Letta ${ }^{2}$, Tilahun Bayisa ${ }^{1}$, Mohamed Abinasa ${ }^{5}$, Ayalneh Tilahun ${ }^{3}$, \\ Bekele Hundie $^{4}$, Wubishet Alemu ${ }^{1}$, Mulatu Abera ${ }^{1}$ \\ ${ }^{1}$ Oromia Agricultural Research Institute, Sinana Agricultural Research Center, Bale-Robe, Ethiopia \\ ${ }^{2}$ Oromia Agricultural Research Institute, Addis Ababa, Ethiopia \\ ${ }^{3}$ International Maize and Wheat Improvement Center, Addis Ababa, Ethiopia \\ ${ }^{4}$ Ethiopia Institute of Agricultural Research, Kulumsa Agricultural Research Center, Assela, Ethiopia \\ ${ }^{5}$ International Centre of Agricultural Research in the Dry Areas, Addis Ababa, Ethiopia \\ Email address: \\ gutamesa@gmail.com (T. Mideksa) \\ ${ }^{*}$ Corresponding author
}

\section{To cite this article:}

Tamene Mideksa, Tesfaye Letta, Tilahun Bayisa, Mohamed Abinasa, Ayalneh Tilahun, Bekele Hundie, Wubishet Alemu, Mulatu Abera. Bread Wheat Varietal Development and Release in Southeastern Highlands of Ethiopia. American Journal of Biological and Environmental Statistics. Vol. 4, No. 1, 2018, pp. 15-19. doi: 10.11648/j.ajbes.20180401.13

Received: November 26, 2017; Accepted: January 4, 2018; Published: January 19, 2018

\begin{abstract}
Four improved bread wheat varieties; Mandoyu (WORRAKATTA/PASTOR), Sanate (14F/HAR1685), Obora (UTIQUE96/FLAG-1) and Dambel (AGUILAL/3/PYN/BAU//MILAN) are developed from ICARDA materials and released in 2014 and 2015, respectively for highland and mid altitude areas of Bale and similar agro-ecologies. The new varieties were tested along with three standard checks (Madawalabu, Sofumer and Tusie) and one local check (Hollandi) at three environments in 2011 to 2012 and 2012 to 2013, respectively during main cropping seasons. The two years data of regional variety trial combined over locations and years provide the newly released varieties showed that superior in grain yield performance, stability, and wide adaptation. The four newly released varieties have good protein content, good physical grain quality, resistant to stem rust, moderately susceptible to yellow rust, moderately resistant to septoria leaf blotch and comparable for leaf rust disease with the checks. The variety Mandoyu, Sanate, Obora and Dambal have been demonstrated and are being cultivated by farmers for production purpose. Hence, the cultivation of these newly released improved bread wheat varieties in the highland and mid altitude areas of major wheat growing environments of the country is highly recommended. This new variety given local name Mandoyu, Sanate, Obora and Dambel, respectively.
\end{abstract}

Keywords: Wheat Variety, Grain Yield, Grain Quality, Protein Content, Wheat Diseases

\section{Introduction}

Wheat (Triticum aestivum L.) is one of the most important crops in the world in production and nutrition. Annually, wheat is produced on 224.53 million hectares of land and 672.2 million metric tons of wheat is produced in the world [10]. In Ethiopia, wheat is one of the most important cereal crops widely cultivated. It is cultivated both in bi-modal and uni-modal rain fall areas. Bread wheat (Triticum aestivum L.) and durum wheat (T. turgidum L. var. durum) are the two species which are mainly cultivated by small scale farmers in
Ethiopia. It ranks fourth in area coverage next to teff, maize and sorghum, respectively [7]. It is the main staple food for about $36 \%$ of the Ethiopian population [4], [5]. Arsi and Bale highlands are the major wheat producing regions of Ethiopia [2] and are deemed to be the wheat belts of East Africa. The area under wheat production is estimated to be about 1.6 million hectares, which makes the country the largest wheat producer in sub-Saharan Africa [6], [8]. Wheat production constrained by various biotic and abiotic factors. Among the biotic factors, fungal diseases are one of the most important biotic constraints threatening wheat production in Ethiopia [1], [9]. Recently, rusts (stem, yellow and leaf rust) and 
septoria leaf blotch and fusarium head blight are significantly threatening wheat production in most of wheat producing agro-ecologies [3]. To alleviate these constraints confronting wheat production, wheat breeding program at Sinana has been working on development of wheat varieties with high yield potential and resistance to major wheat diseases. Development of high yielding varieties requires a thorough knowledge of the existing genetic variation for yield and its components. The successful process of wheat breeding is based on the knowledge of characteristics of genotypes, environment and its interaction. The ideal cultivar for high grain yield or for any other desirable traits needs to express genetic potential with low value of variance in different environmental factors of growing. Therefore, generating more new improved production technologies on wheat must be continues to contribute in food self-sufficiency and sustainable agriculture and could be source of income generation for the local farmers. The objective of the present study was to develop high yielding and disease resistant bread wheat varieties suitable for optimum environments.

\section{Materials and Methods}

\subsection{Breeding Material and Its Background}

Initially more than 2000 bread wheat genotypes received from ICARDA and evaluated under field conditions in augmented design. The best promising genotypes were selected on the basis of maturity, diseases and advanced to preliminary yield trial for further test.

\subsection{Experimental Site and Field Experiment}

The experiment was conducted at three locations for two years (2011 to 2012) and the other experiment was also carried out at the same locations for two consecutive years (2012 to 2013) during main cropping seasons. One of the experiment was conducted at the research farm of Sinana Agricultural Research Center, and the other three sites in the farmer's fields; Robe, Goba and Agarfa. The experiment was conducted from regional variety trial till to the verification trial in 2011 to 2012 and 2012 to 2013 , respectively at each locations on vertisol clay-loam soil under rain fed conditions during meher seasons (AugustJanuary). Sinana Research Center $\left(7^{\circ} \mathrm{N}\right.$ latitude and $40^{\circ} \mathrm{E}$ longitude; and $2400 \mathrm{~m}$ a.s.l) is located $463 \mathrm{~km}$ southeast of Addis Ababa and east of Robe town of Bale zone. Robe is located $33 \mathrm{~km}$ from Sinana in the southeast direction. Goba is located $37 \mathrm{~km}$ from Sinana and about $14 \mathrm{~km}$ from Robe in the south west direction, and Agarfa is located $63 \mathrm{~km}$ from Sinana and $30 \mathrm{~km}$ from Robe town in the Northeast direction.

Sixty-four bread wheat genotypes selected from ICARDA materials and promoted to preliminary yield trial for further evaluation. Sixty-four wheat genotypes were evaluated along with standard and local checks using simple lattice design at Sinana research center in 2010 main cropping season for one year. During this time, agronomic data was collected in plot basis. Out of sixty-four bread wheat tested, fifteen promising bread wheat genotypes were selected and promoted to regional variety trial. Eighteen bread wheat genotypes were evaluated including one standard (Madawalabu) check and one local check (Hollandi) under field condition for two consecutive years (2011 to 2012) at three locations (Sinana, Robe and Goba) using simple lattice design with three replications. Finally, two best promising bread wheat candidates (WORRAKATTA/PASTOR) and (14F/HAR 1685) were identified for final release (Table 1).

Similarly, forty-nine bread wheat lines selected from ICARDA materials and best lines advanced to preliminary yield trial. In the preliminary yield trial, bread wheat lines were tested along with standard and local checks at Sinana research center in 2011 main cropping season for one year. Out of forty-nine, twenty-three bread wheat lines were selected and advanced to regional variety trial. In multilocation trial, twenty-five bread wheat lines were tested including two standard checks (Sofumer and Tusie) and one local check (Hollandi) at three locations (Sinana, Goba and Agarfa) for two consecutive years (2012 to 2013) using simple lattice design with three replications. All agronomic practices were done as recommended for wheat. Agronomic and yield data collected and subjected to statistical analysis to identify the best promising bread wheat genotypes among the evaluated genotypes. Finally, two best candidate varieties (UTIQUE 96 /FLAG-1) and (AGUILAL / 3 / PYN / BAU // MILAN) were identified for possible release (Table 2).

Finally, the most promising candidate varieties evaluated along with standard checks on $10 \mathrm{~m} \times 10 \mathrm{~m}$ plots by the National Variety Releasing Committee at their respective locations in 2013 and 2014, respectively and was been released fully four improved bread wheat varieties for the highland and mid altitude areas of Bale and similar agro-ecologies.

\section{Results and Discussion}

\subsection{Varietal Characteristics}

Mandoyu (WORRAKATTA/PASTOR) is the improved bread wheat variety released in 2014 for mid and highlands of Bale and similar agro-ecologies. This variety is characterized by an erect growth habit and compact ear types. It has white seed color. On average this variety required 68 days for heading, 139 days need to reach physiological maturity and the average plant height is $85 \mathrm{~cm}$ (Table 1). The average weight of thousand kernel is 36.2 and test weight is $81 \mathrm{~kg} / \mathrm{hl}$ (Table 1). This variety is resistant to stem rust and moderately susceptible to yellow rust.

Sanate (14F/HAR 1685$)$ is the newly released bread wheat variety in 2014 for highlands of Bale and similar agroecologies. The variety has compact ear types and erect growth habit. It has amber seed color. On average the variety needs 71 days to heading and 141 days requires to reach physiological maturity, with the average plant height is 102 $\mathrm{cm}$ (Table 1). The average weight of thousand kernel of this new variety is 39.5 and test weight is $80 \mathrm{~kg} / \mathrm{hl}$ (Table 1). The variety is resistant to stem rust and moderately susceptible to yellow rust. 
Table 1. Mean grain yield, other agronomic traits and diseases reaction of Mandoyu, Sanate and the checks in multi-location test during $2011-2012$.

\begin{tabular}{|c|c|c|c|c|c|c|c|c|c|c|c|}
\hline SN & Genotypes & Dh & Dm & Plh & Tkw & Tw & Gy & $\mathbf{Y r}$ & $\mathrm{Sr}$ & $\mathbf{L r}$ & Sep \\
\hline 1 & WORRAKATTA/PASTOR (Mandoyu) & 68 & 139 & 85 & 36.2 & 81.5 & 4275.5 & $10 \mathrm{~ms}$ & $\operatorname{Tr}$ & $5 \mathrm{~ms}$ & 82 \\
\hline 2 & 14F/HAR 1685 (Sanate) & 71 & 141 & 102 & 39.5 & 80 & 4238.6 & $5 \mathrm{~ms}$ & $5 \mathrm{~ms}$ & $5 \mathrm{~ms}$ & 81 \\
\hline 3 & Sofumer (Standard check) & 67 & 136 & 97 & 39.8 & 72 & 3571.5 & $5 \mathrm{~ms}$ & $30 \mathrm{~s}$ & $5 \mathrm{~ms}$ & 82 \\
\hline 4 & Tusie (Standard check) & 68 & 139 & 98 & 34.6 & 73 & 3684 & $10 \mathrm{~ms}$ & $50 \mathrm{~s}$ & $5 \mathrm{~ms}$ & 82 \\
\hline 5 & Hollandi (Local check) & 66 & 138 & 119 & 40.4 & 72 & 3126.2 & $60 \mathrm{~s}$ & $30 \mathrm{~s}$ & $5 \mathrm{~ms}$ & 84 \\
\hline
\end{tabular}

$\mathrm{Dh}=$ days to heading, $\mathrm{Dm}=$ days to maturity, $\mathrm{Plh}=$ plant height $(\mathrm{cm}), \mathrm{Tkw}=$ thousand kernel weight $(\mathrm{g}), \mathrm{Tw}=$ test weight $(\mathrm{kg} / \mathrm{hl}), \mathrm{Gy}=\mathrm{grain}$ yield $(\mathrm{kg} / \mathrm{ha}), \mathrm{Yr}=$ yellow rust, $\mathrm{Sr}=$ stem rust, $\mathrm{Lr}=$ leaf rust, $\mathrm{Sep}=$ Septoria.

Obora (UTIQUE96/FLAG-1) is the newly released bread wheat variety in 2015 for mid and highlands of Bale and similar agro-ecologies. The variety is characterized by having an erect growth habit and compact ear types. It has white seed color. Obora variety on average needs 73 days to heading and 144 days to reach physiological maturity, with the average plant height is $94 \mathrm{~cm}$ (Table 2). The average weight of thousand kernel of this new variety is 39 gram and test weight is $82.1 \mathrm{~kg} / \mathrm{hl}$ (Table 2). This variety is resistant to major wheat diseases.
Dambal (AGUILAL/3/PYN/BAU//MILAN) is the improved bread wheat variety released in 2015 for highland of Bale and similar agro-ecologies. This variety is characterized by having slightly red to amber seed color. It has an erect growth habit and compact ear types. The variety requires 69 days to heading and 142 days needs to reach physiological maturity and with the average plant height being $101 \mathrm{~cm}$ (Table 2). The average weight of thousand kernel is 41.2 and test weight is $81.7 \mathrm{~kg} / \mathrm{hl}$ (Table 2). This variety is resistant to major wheat diseases.

Table 2. Mean grain yield, other agronomic traits and diseases reaction of Obora, Dambal and the checks in multi-location test during $2012-2013$.

\begin{tabular}{|c|c|c|c|c|c|c|c|c|c|c|c|}
\hline SN & Genotypes & Dh & Dm & Plh & Tkw & Tw & Gy & Yr & $\mathbf{S r}$ & $\mathbf{L r}$ & Sep \\
\hline 1 & $\begin{array}{l}\text { ICARDA ELITE SRR-ON Summer } 09 \\
\text { (Kenya+Ethiopa)-107 (Obora) }\end{array}$ & 73 & 144 & 94 & 39 & 82.1 & 4253.8 & Trmr & $5 \mathrm{~ms}$ & $10 \mathrm{~ms}$ & 81 \\
\hline 2 & AGUILAL/3/PYN/BAU//MILAN (Dambal) & 69 & 142 & 101 & 41.2 & 81.7 & 4578.7 & $5 \mathrm{mr}$ & $10 \mathrm{~ms}$ & $10 \mathrm{~ms}$ & 81 \\
\hline 3 & Madawalabu (Standard check) & 69 & 143 & 101 & 42 & 78.8 & 3797.1 & $5 \mathrm{mr}$ & $40 \mathrm{~s}$ & $15 \mathrm{~ms}$ & 94 \\
\hline 4 & Hollandi (Local check) & 65 & 140 & 116 & 38 & 79.4 & 3239.8 & Trmr & $40 \mathrm{~s}$ & $10 \mathrm{~ms}$ & 87 \\
\hline
\end{tabular}

$\mathrm{Dh}=$ days to heading, $\mathrm{Dm}=$ days to maturity, $\mathrm{Ph}=$ plant height $(\mathrm{cm}), \mathrm{Tkw}=$ thousand kernel weight $(\mathrm{g}), \mathrm{Tw}=$ test weight $(\mathrm{kg} / \mathrm{hl}), \mathrm{Gy}=\mathrm{grain}$ yield $(\mathrm{kg} / \mathrm{ha}), \mathrm{Yr}=$ yellow rust, $\mathrm{Sr}=$ stem rust, $\mathrm{Lr}=$ leaf rust, $\mathrm{Sep}=$ Septoria.

\subsection{Grain Yield Performance}

Mandoyu (WORRAKATTA/PASTOR) is characterized by having higher seed grain than the standard check so far released. It has better grain yield advantage of $20 \%, 16 \%$ and $36 \%$ over standard check Sofumer, Tusie and local check Hollandi, respectively (Table 1). The variety gives grain yield of 4.9 to $5.8 \mathrm{tha}^{-1}$ on the research field whereas it gives 2.7 to $4.2 \mathrm{t} \mathrm{ha}^{-1}$ on farmers' field (Table 3 ).

Sanate (14F/HAR 1685) variety has high seed grain than the standard check. It has better grain yield advantage of $18.6 \%$, $15 \%$ and $35.5 \%$ over standard check Sofumer, Tusie and local check Hollandi, respectively (Table 1). This variety gives grain yield of 5.28 to $6.69 \mathrm{t} / \mathrm{ha}^{-1}$ on the research field whereas it gives 3.25 to $4.29 \mathrm{t} \mathrm{ha}^{-1}$ on farmers' field (Table 3 ).

Table 3. Combined mean grain yield and other agronomic traits of bread wheat regional variety trial over years (2011-2012) and over locations (Sinana, Robe and Goba).

\begin{tabular}{|c|c|c|c|c|c|c|c|}
\hline SN & Genotypes & $\mathbf{D h}^{++}$ & $\mathbf{D m}^{++}$ & Plh $^{++}$ & $\mathbf{T k w}^{++}$ & Tw & $\mathbf{G y}^{++}$ \\
\hline 1 & $\begin{array}{l}\text { SAKER/5/RBS/ANZA/KVZ/HYS//YMH/TOB/4/ } \\
\text { BOW'S/PEWIT3/7/ANTA-1 }\end{array}$ & $69.33 \mathrm{cdef}$ & $137.11 \mathrm{gh}$ & $82.78 \mathrm{i}$ & $36.12 \mathrm{~h}$ & 68.3 & $3767.1 \mathrm{defg}$ \\
\hline 2 & SAMAR-8/KAUZ'S//CHAM-4/SHUHA'S/ & $67.11 \mathrm{fg}$ & $137.78 \mathrm{efg}$ & $92.50 \mathrm{fgh}$ & $34.22 \mathrm{i}$ & 68.9 & $3747.2 \mathrm{defg}$ \\
\hline 3 & EALME4SA-167 & $67.22 \mathrm{fg}$ & $135.22 \mathrm{i}$ & $89.61 \mathrm{~h}$ & $37.71 \mathrm{fg}$ & 68.2 & $3720.9 \mathrm{efg}$ \\
\hline 4 & SKAUZ/BAV92 & $70.28 \mathrm{bcd}$ & $138.89 \mathrm{de}$ & $99.67 d$ & $37.13 \mathrm{gh}$ & 69.0 & 3814.9def \\
\hline 5 & WORRAKATTA/PASTOR (Mandoyu) & 68.39defg & $138.83 \mathrm{def}$ & $85.33 \mathrm{i}$ & $36.22 \mathrm{~h}$ & 70.6 & $4275.5 \mathrm{a}$ \\
\hline 6 & UTQUE96/3/PYN/BAU//MILLAN & $74.78 \mathrm{a}$ & $139.39 d$ & $91.61 \mathrm{fgh}$ & 39.68 cde & 71.5 & $3966.3 \mathrm{bcd}$ \\
\hline 8 & AGUILAL/3/PYN/BAU//MILLAN & $66.72 \mathrm{~g}$ & $137.94 \mathrm{efg}$ & $91.28 \mathrm{gh}$ & $41.24 \mathrm{ab}$ & 71.1 & $4104.5 \mathrm{abc}$ \\
\hline 9 & ETBW5570 & 68.06defg & $135.11 \mathrm{i}$ & $91.00 \mathrm{gh}$ & $41.13 \mathrm{ab}$ & 70.1 & $4283.4 \mathrm{a}$ \\
\hline 10 & ETBW5572 & $67.50 \mathrm{efg}$ & $137.89 \mathrm{efg}$ & $99.67 d$ & 39.09def & 69.3 & $4183.0 \mathrm{ab}$ \\
\hline 11 & NS732/HER//MILAN/SHA7 & 69.83 bcde & $141.50 \mathrm{c}$ & $94.89 \mathrm{ef}$ & $41.58 \mathrm{a}$ & 71.2 & $4074.8 \mathrm{abc}$ \\
\hline 12 & VEE/PJN//2*TUI/3/2*MILAN/KAUZ & $68.56 \mathrm{cdefg}$ & $137.61 \mathrm{fg}$ & $94.22 \mathrm{efg}$ & $40.28 \mathrm{abcde}$ & 72.3 & $4155.9 \mathrm{abc}$ \\
\hline 13 & $15 \mathrm{~F} / \mathrm{HAR} 710$ & $70.44 \mathrm{bcd}$ & $141.94 b c$ & $112.67 \mathrm{~b}$ & $38.92 \mathrm{ef}$ & 72.0 & $3931.5 \mathrm{cde}$ \\
\hline 14 & 14F/HAR1685 (Sanate) & $75.11 \mathrm{a}$ & $142.94 \mathrm{ab}$ & $103.83 \mathrm{de}$ & $36.02 \mathrm{~h}$ & 71.5 & $4238.6 \mathrm{a}$ \\
\hline 16 & Sofumer (standard check) & $67.22 \mathrm{fg}$ & 135.94hi & $96.83 \mathrm{de}$ & $39.87 \mathrm{bcde}$ & 72.0 & $3571.5 \mathrm{~g}$ \\
\hline 17 & Tusie (standard check) & $68.44 \mathrm{defg}$ & $139.22 \mathrm{~d}$ & $98.78 \mathrm{~d}$ & $34.58 \mathrm{i}$ & 73.0 & $3684.0 \mathrm{fg}$ \\
\hline
\end{tabular}




\begin{tabular}{|c|c|c|c|c|c|c|}
\hline $\begin{array}{ll}\text { SN } & \text { Genotypes }\end{array}$ & $\overline{\text { Dh }^{++}}$ & $\overline{\text { Dm }^{++}}$ & $\overline{\text { Plh }^{++}}$ & $\mathbf{T k w}^{++}$ & $\overline{T w}$ & $\overline{G^{++}}$ \\
\hline $18 \quad$ Hollandi (local check) & $66.39 \mathrm{~g}$ & $138.22 \mathrm{defg}$ & $119.89 \mathrm{a}$ & 40.39abcd & 71.9 & $3126.2 \mathrm{~h}$ \\
\hline Mean & 69.36 & 138.77 & 96.22 & 38.43 & 70.8 & 3927.3 \\
\hline CV (\%) & 5.3 & 1.4 & 5.6 & 5.5 & & 91 \\
\hline SE & 0.858 & 0.453 & 1.265 & 0.498 & & 81.983 \\
\hline $\operatorname{LSD}(5 \%)$ & 2.364 & 1.263 & 3.527 & 1.389 & & 234.17 \\
\hline
\end{tabular}

* Dh: days for heading, Dm: days to maturity, Plh: plant height (cm), TKW: thousand kernel weight (gm), TW: test weight (kg/hl), Gy: grain yield (kg/ha), Sr: stem rust (\%), Yr: yellow rust (\%), Lr: leaf rust (\%), S: susceptible, MS: moderately susceptible, MR: moderately resistant, Tr: trace, Trms: trace with moderately susceptible, Trmr: trace with moderately resistant, R: resistant, CV (\%): coefficient of variations, SE: standard error of the mean, LSD: least significant differences, ++ Means within each column followed by the same letter are not significantly different from each other based on the 0.05 probability level of LSD.

Obora (UTIQUE96/FLAG-1) has high grain yield than the standard check so far released. It has better grain yield advantage of $12 \%$ over standard check Madawalabu and $31.3 \%$ over local check Hollandi (Table 2). This variety gives grain yield of 4.68 to $6.31 \mathrm{t} \mathrm{ha}^{-1}$ on the research field whereas it gives 3.3 to $3.75 \mathrm{t} \mathrm{ha}^{-1}$ on farmers' field (Table 4).
Dambal (AGUILAL/3/PYN/BAU//MILAN) has high grain yield as compared to standard check. It has better grain yield advantage of $20.58 \%$ over standard check Madawalabu and $41.32 \%$ over local check Hollandi (Table 2). This variety gives grain yield of 5.63 to $6.37 \mathrm{tha}^{-1}$ on the research field whereas it gives 3.38 to $4.19 \mathrm{t} \mathrm{ha}^{-1}$ on farmers' field (Table 4).

Table 4. Combined mean grain yield and other agronomic traits of bread wheat regional variety trial over years (2012-2013) and over locations (Sinana, Goba and Agarfa).

\begin{tabular}{|c|c|c|c|c|c|c|c|}
\hline SN & Genotypes & $\mathbf{D h}^{++}$ & $\mathbf{D m}^{++}$ & Plh $^{++}$ & $\mathbf{T k w}^{++}$ & Tw & $\mathbf{G y} \mathbf{y}^{++}$ \\
\hline 1 & ICARDA ELITE SRR-ON Summer 09-257 & $69.39^{\text {cde }}$ & $143.44^{\mathrm{bcd}}$ & $91.72^{\text {hij }}$ & $35.49^{\mathrm{h}}$ & 81.9 & $3900.3^{\text {defghi }}$ \\
\hline 2 & ICARDA ELITE SRR-ON Summer 09-258 & $69.44^{\mathrm{cd}}$ & $143.61^{\text {bcd }}$ & $94.00^{\text {ghi }}$ & $35.26^{\mathrm{h}}$ & 80.7 & $4046.1^{\text {cdef }}$ \\
\hline 3 & ICARDA ELITE SRR-ON Summer 09-263 & $66.56^{\mathrm{ij}}$ & $142.50^{\mathrm{def}}$ & $98.94^{\text {cde }}$ & $36.93^{\mathrm{fg}}$ & 80.3 & $3525.3^{\mathrm{jklm}}$ \\
\hline 4 & ICARDA ELITE SRR-ON Summer 09-308 & $70.39^{\mathrm{b}}$ & $143.44^{\text {bcd }}$ & $77.28^{\mathrm{k}}$ & $37.32^{\mathrm{ef}}$ & 80.1 & $3865.7^{\text {efghi }}$ \\
\hline 5 & ICARDA ELITE SRR-ON Summer 09 (Kenya+Ethiopia)-4 & $66.72^{\mathrm{ij}}$ & $143.11^{\text {cde }}$ & $112.06^{\mathrm{ab}}$ & $39.20^{\mathrm{d}}$ & 81.4 & $4052.4^{\text {cdef }}$ \\
\hline 6 & ICARDA ELITE SRR-ON Summer 09 (Kenya+Ethiopia)-98 & $67.94^{\mathrm{gh}}$ & $139.67^{\mathrm{i}}$ & $91.11^{\mathrm{ij}}$ & $29.97^{\mathrm{jk}}$ & 79.9 & $3597.9^{\mathrm{ijkl}}$ \\
\hline 7 & ICARDA ELITE SRR-ON Summer 09 (Kenya+Ethiopia)-103 & $68.28^{\mathrm{fg}}$ & $139.78^{\text {hi }}$ & $91.44^{\mathrm{ij}}$ & $31.22^{\mathrm{j}}$ & 80.1 & $3851.5^{\text {efghi }}$ \\
\hline 8 & ICARDA ELITE SRR-ON Summer 09 (Kenya+Ethiopia)-107 & $72.67 \mathrm{a}$ & $144.44 b$ & 93.94ghi & $39.03 \mathrm{~d}$ & 82.1 & $4253.8 \mathrm{c}$ \\
\hline 9 & ICARDA ELITE SRR-ON Summer 09 (Kenya+Ethiopia)-114 & $66.39^{\mathrm{ijk}}$ & $140.78^{\mathrm{ghi}}$ & $92.33^{\mathrm{hij}}$ & $41.63^{\mathrm{bc}}$ & 81.2 & $4088.1^{\text {cde }}$ \\
\hline 10 & ICARDA ELITE SRR-ON Summer 09 (Kenya+Ethiopia)-115 & $66.11^{\mathrm{jk}}$ & $140.72^{\text {ghi }}$ & $97.61^{\text {cdefg }}$ & $43.89^{\mathrm{a}}$ & 80.9 & $4196.3^{\mathrm{cd}}$ \\
\hline 11 & CHIL-1//VEE'S/SAKER'S' & $67.17^{\mathrm{hi}}$ & $142.72^{\mathrm{def}}$ & $97.39^{\text {cdefg }}$ & $36.52^{\text {fgh }}$ & 80.6 & $3410.8^{\operatorname{lm}}$ \\
\hline 12 & LOUOU-3 & $66.56^{\mathrm{ij}}$ & $144.17^{\mathrm{bc}}$ & $97.00^{\operatorname{defg}}$ & $38.54^{\mathrm{de}}$ & 79.5 & $3439.6^{\mathrm{klm}}$ \\
\hline 13 & ICBW206974 (Sr35) & $69.44^{\mathrm{cd}}$ & $140.33^{\text {hi }}$ & $89.44^{\mathrm{j}}$ & $32.66^{\mathrm{i}}$ & 81.1 & $3633.7^{\text {hijkl }}$ \\
\hline 14 & PBW343 (Sr24) & $72.67^{\mathrm{a}}$ & $145.61^{\mathrm{a}}$ & $95.94^{\text {efgh }}$ & $35.53^{\mathrm{h}}$ & 80.1 & $4206.2^{\mathrm{cd}}$ \\
\hline 15 & CHIL-1/ICARDA-SRRL-7 & $68.50^{\text {efg }}$ & $142.78^{\mathrm{def}}$ & $96.83^{\text {defg }}$ & $36.26^{\mathrm{fgh}}$ & 80.9 & $3688.1^{\text {ghijkl }}$ \\
\hline 17 & ETBW 5565 & $69.89^{\mathrm{bc}}$ & $139.67^{\mathrm{i}}$ & $96.17^{\text {efgh }}$ & $36.01^{\text {gh }}$ & 80.2 & $4650.6^{\mathrm{a}}$ \\
\hline 18 & ETBW 5586 & $68.22^{\mathrm{fg}}$ & $140.83^{\mathrm{gh}}$ & $98.67^{\text {cdef }}$ & $38.51^{\mathrm{de}}$ & 80.3 & $3972.3^{\text {cdefg }}$ \\
\hline 19 & AGUILAL/3/PYN/BAU//MILAN & $69.11^{\text {cdef }}$ & $141.78^{\mathrm{fg}}$ & $101.50^{\mathrm{c}}$ & $41.19^{c}$ & 81.7 & $4578.7^{\mathrm{ab}}$ \\
\hline 20 & UTQUE96/3/PYN/BAU//MILAN & $68.67^{\text {defg }}$ & $143.11^{\text {cde }}$ & $100.17^{\text {cde }}$ & $42.00^{\mathrm{bc}}$ & 81.6 & $4257.0^{\mathrm{bc}}$ \\
\hline 21 & SABA/3/PYN/BAU//MILAN & $69.39^{\text {cde }}$ & $139.89^{\mathrm{hi}}$ & $94.33^{\text {fghi }}$ & $29.24^{\mathrm{k}}$ & 78.5 & $3739.6^{\text {fghijk }}$ \\
\hline 22 & ETBW 5517 & $68.22^{\mathrm{fg}}$ & $142.28^{\mathrm{ef}}$ & $79.78^{\mathrm{k}}$ & $38.60^{\mathrm{d}}$ & 80.1 & $4059.0^{\text {cdef }}$ \\
\hline 23 & ETBW 5519 & $69.94^{\mathrm{bc}}$ & $143.00^{\mathrm{de}}$ & $91.94^{\mathrm{hij}}$ & $37.19^{\mathrm{fg}}$ & 80.6 & $3926.7^{\text {defgh }}$ \\
\hline 24 & Madawalabu (Standard check) & $68.61^{\text {defg }}$ & $142.67^{\mathrm{def}}$ & $100.72^{\mathrm{cd}}$ & $42.59^{\mathrm{b}}$ & 78.8 & $3797.1^{\text {efghij }}$ \\
\hline 25 & Hollandi (Local check) & $65.56^{\mathrm{k}}$ & $140.22^{\mathrm{hi}}$ & $116.39^{\mathrm{a}}$ & $38.55^{\mathrm{de}}$ & 79.4 & $3239.8^{\mathrm{m}}$ \\
\hline \multicolumn{2}{|c|}{ Mean } & 68.5 & 142.1 & 96.3 & 37.4 & 80.6 & 3929.2 \\
\hline \multicolumn{2}{|c|}{$\mathrm{CV}(\%)$} & 2.1 & 1.2 & 7.1 & 5.2 & 1.6 & 12.6 \\
\hline \multicolumn{2}{|c|}{$\mathrm{SE}$} & 0.33 & 0.42 & 1.61 & 0.46 & 0.52 & 116.262 \\
\hline \multicolumn{2}{|c|}{ LSD (5\%) } & 0.93 & 1.16 & 4.48 & 1.27 & 1.47 & 323.58 \\
\hline
\end{tabular}

*Dh: days for heading, Dm: days to maturity, Plh: plant height (cm), Tkw: thousand kernel weight (cm), Tw: test weight (kg/hl), Gy: grain yield (kg/ha), Sr: stem rust (\%), Yr: yellow rust (\%), Lr: leaf rust (\%), S: susceptible, MS: moderately susceptible, MR: moderately resistant, Trmr: trace with moderately resistant, Tr: trace, Trr: trace with resistant, R: resistant, CV (\%): coefficient of variations, SE: standard error of the mean, LSD: least significant differences, ++ Means within each column followed by the same letter are not significantly different from each other based on the 0.05 probability level of LSD.

\subsection{Reaction to the Major Wheat Diseases and Quality Traits}

The newly released bread wheat varieties resistance / tolerance to stem rust, moderately susceptible to yellow rust, moderately resistance to septoria leaf blotch and comparable for leaf rust disease with the checks (Table 1 and 2). The quality parameters indicates that the newly released variety Obora, Sanate, Mandoyu and Dambal have good percentage of protein content and gluten content, which ranges from 12.1 to $15.9 \%$ and 25.9 to $37.4 \%$, respectively (Table 5). 
Table 5. Quality parameters of improved bread wheat varieties recently released from SARC.

\begin{tabular}{|c|c|c|c|c|c|c|c|}
\hline \multirow[b]{2}{*}{ SN } & \multirow[b]{2}{*}{ Variety } & \multicolumn{6}{|c|}{ Quality parameters } \\
\hline & & TKW* (g) & HLW* $\left(\mathrm{kghl}^{-1}\right)$ & Gluten (\%) & Moisture content (\%) & Protein (\%) & $\begin{array}{l}\text { Zeleny index } \\
\text { (ml) }\end{array}$ \\
\hline 1 & Senate (14F/HAR1685) & 39.1 & 75.2 & 29.6 & 12.7 & 13.9 & 58.9 \\
\hline 2 & Mandoyu (WORRAKATTA/PASTOR & 32.5 & 80.0 & 31.1 & 11.5 & 13.7 & 63.6 \\
\hline 3 & Obora (UTIQUE96/FLAG-1) & 37.2 & 80.0 & 37.4 & 11.0 & 15.9 & 79.3 \\
\hline 4 & Dambal (AGUILAL/3/PYN/BAU//MILAN) & 46.3 & 83.6 & 25.9 & 11.7 & 12.1 & 48.1 \\
\hline
\end{tabular}

*TKW= thousand kernel weight, $\mathrm{HLW}=$ hectoliter weight, $\mathrm{SN}=$ serial number.

\subsection{Adaptation}

Mandoyu variety released for mid and high altitude areas of Bale whereas Sanate variety released for highlands of Bale and similar agro-ecologies. These two improved bread wheat varieties perform very well in area having an altitude 2200 to 2500 and 2300 to $2600 \mathrm{~m}$ a.s.l, respectively with the annual rainfall of $750-1500 \mathrm{~mm}$. The two improved bread wheat varieties are better if planting is done from mid-June to late August based on the agro-ecology of the area.

Obora and Dambal varieties are released for highlands of Bale and similar agro-ecologies. These two improved bread wheat varieties perform very well in area having an altitude 2000 to $2400 \mathrm{~m}$ a.s.1 with the annual rainfall of 750-1500 $\mathrm{mm}$. Both two improved bread wheat varieties are better if planting is done from mid-June to early September based on the agro-ecology of the area.

\section{Conclusions}

Mandoyu, Sanate, Obora and Dambal are the best varieties identified and verified along with standard checks and local check in multi-location trials across the testing environments with superior in grain yield performance, yield stability and wide adaptation. They have better agronomic performance with resistance to stem rust disease compared to the standard checks. Hence, cultivation of the new varieties are recommended in major wheat growing regions of the country having similar agro-ecologies with the testing environments.

\section{Acknowledgements}

The authors are grateful to SARD-SC wheat project for financial support and Oromia Agricultural Research Institute and Sinana Agricultural Research Center for provision of facilities, implementation of the experiment.

\section{References}

[1] Ayele B., Solomon A., and Fehrmann H. 2008. Yellow Rust Resistance in Advanced lines and Commercial Cultivars of bread wheat from Ethiopia. East African Journal of Sciences. 2: 29-34.

[2] Bekele Hundie, Verkuiji, H., Mawangi, W. and Tanner, D. G. 2000. Adaptation of improved wheat technologies in Adaba and Dodola Woredas of the Bale highlands of Ethiopia. CIMMYT/EARO, Addis Ababa, Ethiopia.

[3] Bekele Hundie and Dereje Hailu. 2003. Short report on yellow rust and stem rust. In: Bedada Girma (ed.). Bale Agricultural Development Enterprise: Proceedings of the Agronomy Workshop. March 20-21, Melkassa, Ethiopia. pp. 67-78.

[4] CIMMYT (International Center for Maize and Wheat Improvement). 2005. Sounding the alarm on global stem rust: An assessment of race Ug99 in Kenya and Ethiopia and the potential for impact in neighboring regions and beyond. Expert Panel Report. International Center for Maize and Wheat Improvement (CIMMYT), Mexico. 26 p.

[5] CSA (Central Statistical Authority). 2004. Agricultural survey sample. Report on area and production of crops (private peasant holdings, meher season). Statistical Bulletin No 33. Addis Ababa, Ethiopia.

[6] CSA (Central Statistical Agency). 2011. Large and Medium Scale Commercial Farms Sample Survey. Statistical Report on Area and Production of Crops, and Farm Management Practices. Statistical Bulletin 505. Addis Ababa, Ethiopia.

[7] CSA (Central Statistical Authority). 2014. Agricultural survey sample. Report on area and production of crops (private peasant holding, meher season). Statistical Bulletin No 278. Addis Ababa, Ethiopia.

[8] Hailu, G. M. 1991. Wheat production and research in Ethiopia pp: 1-15. In: Hailu G, Tanner, DG. and Mengistu H (eds). Wheat research in Ethiopia: A historical perspective. Addis Ababa, IAR/CIMMYT.

[9] Mengistu, H., Getaneh, W., Yeshi, A., Rebeka D. and Ayele, B. 1991. Wheat pathology research in Ethiopia. pp 173-217. In: G. Hailu, D. G. Tanner and H. Mengistu (ed.) Wheat Research in Ethiopia: A historical perspective. Addis Ababa. IAR/CIMMYT.

[10] USDA (United States Department of Agriculture) (2010). World Agricultural Production. Circular series. May 05-10. 